\title{
Trichinella Outbreaks on Pig Farms in Poland in 2012-2020
}

\author{
Ewa Bilska-Zając ${ }^{1}$, Mirosław Różycki ${ }^{1}$ (D), Weronika Korpysa-Dzirba ${ }^{1, *}$, Aneta Bełcik ${ }^{1}$, Anna Ziętek-Barszcz ${ }^{2}$, \\ Magdalena Włodarczyk-Ramus ${ }^{1}$, Aneta Gontarczyk ${ }^{1}$ and Tomasz Cencek ${ }^{1}$ (D)
}

1 Department of Parasitology and Invasive Diseases, National Veterinary Research Institute, Partyzantów Avenue, 57, 24-100 Pulawy, Poland; ewa.bilska@piwet.pulawy.pl (E.B.-Z.); mrozycki@piwet.pulawy.pl (M.R.); aneta.belcik@piwet.pulawy.pl (A.B.); magdalena.wlodarczyk@piwet.pulawy.pl (M.W.-R.); aneta.gontarczyk@piwet.pulawy.pl (A.G.); tcencek@piwet.pulawy.pl (T.C.)

2 Department of Epidemiology and Risk Assessment, National Veterinary Research Institute, Partyzantów Avenue, 57, 24-100 Pulawy, Poland; anna.barszcz@piwet.pulawy.pl

* Correspondence: weronika.korpysa@piwet.pulawy.pl

check for updates

Citation: Bilska-Zając, E.; Różycki, M.; Korpysa-Dzirba, W.; Bełcik, A.; Ziętek-Barszcz, A.; Włodarczyk-Ramus, M.;

Gontarczyk, A.; Cencek, T. Trichinella Outbreaks on Pig Farms in Poland in 2012-2020. Pathogens 2021, 10, 1504. https://doi.org/10.3390/ pathogens10111504

Academic Editor: Stefania Perrucci

Received: 23 October 2021

Accepted: 15 November 2021

Published: 18 November 2021

Publisher's Note: MDPI stays neutral with regard to jurisdictional claims in published maps and institutional affiliations.

Copyright: (c) 2021 by the authors. Licensee MDPI, Basel, Switzerland. This article is an open access article distributed under the terms and conditions of the Creative Commons Attribution (CC BY) license (https:// creativecommons.org/licenses/by/ $4.0 /)$.

\begin{abstract}
Trichinella nematodes continue to circulate in various hosts both in the domestic and sylvatic cycles. In the majority of countries in Europe, wild boars have been noticed as a primary source of Trichinella spp. infections in humans. However, in some regions, the meat of pigs containing Trichinella spp. larvae can still be a cause of trichinellosis. Therefore, in the present study, we aimed to determine and present actual data on the occurrence of Trichinella spp. on pig farms (Sus scrofa $f$. domestica) in Poland. In this study, over 194 million pigs, slaughtered for commercial and personal purposes between 2012 and 2020, were tested with a digestion method according to the official rules for Trichinella control. Positive results were noticed in 172 pigs which gives an overall prevalence of $0.000088 \%$. On seven farms, rats (Rattus norvegicus) infected with Trichinella spp. were also discovered. The species identification showed pigs were infected with Trichinella spiralis on 26 farms, and on four farms pigs with Trichinella britovi infections were found. Therefore, it is important to constantly monitor pigs for the presence of these parasites, especially in view of the growing interest in organic meat originated from ecological farms.
\end{abstract}

Keywords: Trichinella spp.; pig; Poland; outbreak; farm

\section{Introduction}

Food safety is a key issue for the global food chain and a daily concern for consumers. Foods containing pathogenic bacteria, viruses, parasites or fungi pose a risk to the health and life of consumers. This increases the demand for health services, government spending on public health and other social costs. In order to prevent the above risks, the European Union has introduced quality assurance programs based on continuous monitoring of the raw material, production process, storage and distribution of final products, for the purpose for which they are intended [1]. Pig meat in Poland is one of the most consumed meats, with more than $40 \mathrm{~kg}$ of pork consumed per capita [2]. As a final product, it can be a source of many zoonoses, including trichinellosis [3]. Trichinellosis is caused by nematodes of the genus Trichinella. The most pathogenic species and the most common cause of this disease in humans is Trichinella spiralis [4]. In Poland, this species is responsible for the majority of infections [5]. This parasite spreads in the natural environment by consuming meat containing live larvae; therefore, carnivores and omnivoresare the most vulnerable to infection. However, herbivores may also be infected occasionally (e.g., due to their protein supplementation or accidentally) [6]. Due to their circulation between different host species, the synanthropic (domestic) and sylvatic (forest) cycles occur. In the synanthropic cycle, the hosts of the parasite are farm animals, primarily pigs, as well as various species of domestic and free-living animals, including rats, mice, cats, etc. living on or near farms. In the sylvatic cycle, there are many species of animals that can be infected with Trichinella spp., 
mainly predatory, carnivorous animals such as wolves, foxes, jackals, bears, and they are the largest reservoir of this parasite. Omnivores, especially wild boars, are lately more and more an important reservoir of Trichinella spp. The domestic cycle and the sylvatic cycle often overlap by common reservoirs such as rodents, living in the fields in summer, and gathering on farms in winter, where they have easy access to food. Rodents can transfer the nematodes both from the sylvatic cycle to the synanthropic cycle and vice versa. Sometimes, man's behaviour is the cause of the parasite transmission between both cycles. This is the case when farm owners feed farmed animals with the remains of hunted animals (wild boar, foxes) or slaughter waste, and also when fallen livestock is illegally transported to the forest. In terms of safety for consumers, infections in the animal population intended for consumption, and therefore mainly pigs and wild boar, are of greatest importance. Historical data indicate that in Europe, pig meat was the most common source of human infection $[7,8]$. This information led to changes in the legislation stating that each pig carcass intended for the market or own purposes must be tested for the presence of Trichinella spp. larvae, and removed from the food chain in case of positive [9]. In 2005 the European Commission has implemented a new regulation no. 2075/2005, laying down specific rules for the official controls of Trichinella in meat in order to improve food safety for European consumers. Apart from pigs, this rule covered wild boars, horses, bears and coypu (EU Regulation 2017/2005) [10]. Subsequent, amendments to this regulation allowed for the possibility of not performing tests on all pigs, as long as they are reared on farms that meet controlled housing conditions EU Regulation 2015/1375 [11]. However, if these conditions are not met, then there is a need to continue to perform tests according to EU Regulation 2020/1478 of 14 October 2020 [12] amending Commission Implementing Regulation (EU) 2015/1375 as regards sampling, the reference method for detection and import conditions related to Trichinella spp. control.

According to EU One Health Zoonoses Report (2019), the main risk factor for Trichinella spp. infections in domestic pigs are non-controlled housing conditions. In recent years, most human cases of trichinellosis were reported from a few countries in the eastern part of Europe and were linked to free-ranging and backyard pigs and farmed wild boar. However, taking into account the 5-year period (2015-2019), there is a decreasing trend in trichinellosis cases in Europe. The reason for this is the increasing number of pigs raised under controlled housing conditions together with the reduction of pigs not kept in these conditions, the farmer's education as well as increased control of slaughtering of free-ranging and backyard pigs. Nevertheless, the reported number of Trichinella-positive domestic pigs may be underestimated as most pigs slaughtered at home are still without veterinary control [13].

Researches and statistics from recent years indicate that wild boar meat is currently the main threat of trichinellosis to Polish consumers [14], and pigs are found to be infected less often [15]. As a result, food producers more and more often are asking about the legitimacy of applying this routine control, which is extremely time-consuming and costly. However, in order for any discussions on this topic to be undertaken, one should get acquainted with the current epidemiological situation regarding this parasite.

Here, we collect and present the latest data on the occurrence of trichinellosis in pigs in Poland in 2012-2020, taking into account the geographical location of farms in which this pathogen was found. We also discuss the need of conducting proper epidemiological investigations on pig farms where Trichinella infected pigs were found in order to stop the spreading of this parasite and find the source of infection.

\section{Results}

Routine diagnostics of trichinellosis conducted by Veterinary Inspection Services (VIS) included 194,449,146 pigs slaughtered in 2012-2020, with average 21,605,460 pigs slaughtered yearly. The positive results come from 30 pig farms in which altogether 172 pigs were infected with Trichinella spp. (Table 1). 
Table 1. List of farms in which Trichinella spp. infected pigs were discovered between 2012 and 2020. The table includes information about geolocation, prevalence, number of rats collected on the farm, number of infected rats and species identification of larvae.

\begin{tabular}{|c|c|c|c|c|c|c|c|c|c|c|}
\hline No. & Year & $\begin{array}{l}\text { Farm } \\
\text { Location }\end{array}$ & Province & $\begin{array}{c}\text { No of Pig in } \\
\text { a Herd }\end{array}$ & $\begin{array}{c}\text { No of } \\
\text { Infected Pig }\end{array}$ & Prevalence & $\begin{array}{c}\text { No of } \\
\text { Collected } \\
\text { Rats }\end{array}$ & $\begin{array}{c}\text { No of } \\
\text { Infected Rats }\end{array}$ & $\begin{array}{c}\text { Access to } \\
\text { Natural } \\
\text { Environment }\end{array}$ & $\begin{array}{l}\text { Species } \\
\text { of } \\
\text { Trichinella }\end{array}$ \\
\hline 1. & 2012 & Oleszno & wielkopolska & 40 & 2 & 5 & None & None & Yes & T. spiralis \\
\hline 2. & 2013 & $\begin{array}{l}\text { Jeziora } \\
\text { Wielkie }\end{array}$ & $\begin{array}{l}\text { kujawsko- } \\
\text { pomorskie }\end{array}$ & 36 & 18 & 50 & 56 & 17 & Yes & T. spiralis \\
\hline 3. & 2013 & $\begin{array}{l}\text { Sliwowo- } \\
\text { Łopienite }\end{array}$ & podlaskie & 83 & 24 & 28.9 & 14 & 1 & Yes & T. spiralis \\
\hline 4. & 2013 & Elblag & $\begin{array}{l}\text { warmińsko- } \\
\text { mazurskie }\end{array}$ & $\mathrm{Nd}$ & 1 & $\mathrm{Nd}$ & $\mathrm{Nd}$ & $\mathrm{Nd}$ & $\mathrm{Nd}$ & T. britovi \\
\hline 5. & 2013 & Gniezno & wielkopolska & $\mathrm{Nd}$ & 1 & $\mathrm{Nd}$ & $\mathrm{Nd}$ & $\mathrm{Nd}$ & $\mathrm{Nd}$ & T. britovi \\
\hline 6. & 2013 & Damasławek & wielkopolska & $\mathrm{Nd}$ & 1 & $\mathrm{Nd}$ & $\mathrm{Nd}$ & $\mathrm{Nd}$ & $\mathrm{Nd}$ & T. spiralis \\
\hline 7. & 2013 & Kościan & wielkopolska & $\mathrm{Nd}$ & 1 & $\mathrm{Nd}$ & $\mathrm{Nd}$ & $\mathrm{Nd}$ & $\mathrm{Nd}$ & T. spiralis \\
\hline 8. & 2013 & Pyrzyce & $\begin{array}{l}\text { zachodnio- } \\
\text { pomorskie }\end{array}$ & $\mathrm{Nd}$ & 1 & $\mathrm{Nd}$ & $\mathrm{Nd}$ & $\mathrm{Nd}$ & $\mathrm{Nd}$ & T. spiralis \\
\hline 9. & 2014 & Rzadkwin & $\begin{array}{l}\text { kujawsko- } \\
\text { pomorskie }\end{array}$ & $\mathrm{Nd}$ & 1 & $\mathrm{Nd}$ & $\mathrm{Nd}$ & $\mathrm{Nd}$ & $\mathrm{Nd}$ & T. spiralis \\
\hline 10. & 2014 & Kwidzyń & pomorskie & $\mathrm{Nd}$ & 1 & $\mathrm{Nd}$ & $\mathrm{Nd}$ & $\mathrm{Nd}$ & $\mathrm{Nd}$ & T. spiralis \\
\hline 11. & 2014 & Kalisz & wielkopolska & $\mathrm{Nd}$ & 1 & $\mathrm{Nd}$ & $\mathrm{Nd}$ & $\mathrm{Nd}$ & $\mathrm{Nd}$ & T. spiralis \\
\hline 12. & 2014 & Rynowo & $\begin{array}{l}\text { zachodnio- } \\
\text { pomorskie }\end{array}$ & 20 & 11 & 55 & 21 & 3 & Yes & T. spiralis \\
\hline 13. & 2015 & Tczew & pomorskie & $\mathrm{Nd}$ & 1 & $\mathrm{Nd}$ & $\mathrm{Nd}$ & $\mathrm{Nd}$ & $\mathrm{Nd}$ & T. spiralis \\
\hline 14. & 2015 & Oborniki & wielkopolska & $\mathrm{Nd}$ & 1 & $\mathrm{Nd}$ & $\mathrm{Nd}$ & $\mathrm{Nd}$ & $\mathrm{Nd}$ & T. britovi \\
\hline 15. & 2015 & Piotrkowice & wielkopolska & 32 & 2 & 6.25 & 10 & None & Yes & T. spiralis \\
\hline 16. & 2015 & Szamotuły & wielkopolska & $\mathrm{Nd}$ & 1 & $\mathrm{Nd}$ & $\mathrm{Nd}$ & $\mathrm{Nd}$ & $\mathrm{Nd}$ & T. spiralis \\
\hline 17. & 2016 & Namysłów & opolskie & $\mathrm{Nd}$ & 1 & $\mathrm{Nd}$ & $\mathrm{Nd}$ & $\mathrm{Nd}$ & $\mathrm{Nd}$ & T. spiralis \\
\hline 18. & 2016 & Elblag & $\begin{array}{l}\text { warmińsko- } \\
\text { mazurskie }\end{array}$ & $\mathrm{Nd}$ & 1 & $\mathrm{Nd}$ & $\mathrm{Nd}$ & $\mathrm{Nd}$ & $\mathrm{Nd}$ & T. spiralis \\
\hline 19. & 2016 & Choszczno & $\begin{array}{l}\text { zachodnio- } \\
\text { pomorskie }\end{array}$ & $\mathrm{Nd}$ & 1 & $\mathrm{Nd}$ & $\mathrm{Nd}$ & $\mathrm{Nd}$ & $\mathrm{Nd}$ & T. spiralis \\
\hline 20. & 2016 & Łobez & $\begin{array}{l}\text { zachodnio- } \\
\text { pomorskie }\end{array}$ & $\mathrm{Nd}$ & 1 & $\mathrm{Nd}$ & $\mathrm{Nd}$ & $\mathrm{Nd}$ & $\mathrm{Nd}$ & T. spiralis \\
\hline 21. & 2017 & Tczew & pomorskie & $\mathrm{Nd}$ & 1 & $\mathrm{Nd}$ & $\mathrm{Nd}$ & $\mathrm{Nd}$ & $\mathrm{Nd}$ & T. spiralis \\
\hline 22. & 2017 & Pelplin & pomorskie & 366 & 11 & 3 & 50 & None & Yes & T. spiralis \\
\hline 23. & 2017 & $\begin{array}{l}\text { Bielsko- } \\
\text { Biała }\end{array}$ & śląskie & $\mathrm{Nd}$ & 1 & $\mathrm{Nd}$ & $\mathrm{Nd}$ & $\mathrm{Nd}$ & $\mathrm{Nd}$ & T. britovi \\
\hline 24. & 2017 & Sławno & $\begin{array}{l}\text { zachodnio- } \\
\text { pomorskie }\end{array}$ & $\mathrm{Nd}$ & 1 & $\mathrm{Nd}$ & $\mathrm{Nd}$ & $\mathrm{Nd}$ & $\mathrm{Nd}$ & T. spiralis \\
\hline 25. & 2018 & Małkowo & pomorskie & 101 & 47 & 46.5 & None & None & No & T. spiralis \\
\hline 26. & 2018 & Dziećmiarki & wielkopolska & 800 & 3 & 0.38 & None & None & No & T. spiralis \\
\hline 27. & 2019 & $\begin{array}{l}\text { Nowy } \\
\text { Tomyśl }\end{array}$ & wielkopolska & 2 & 2 & 100 & 3 & 3 & Yes & T. spiralis \\
\hline 28. & 2019 & Chodzież & wielkopolska & 343 & 18 & 5.2 & 7 & None & $\mathrm{Nd}$ & T. spiralis \\
\hline 29. & 2020 & Wschowa & lubuskie & 52 & 6 & 11.5 & $\mathrm{Nd}$ & $\mathrm{Nd}$ & $\mathrm{Nd}$ & T. spiralis \\
\hline 30. & 2020 & Rosiny & $\begin{array}{l}\text { zachodnio- } \\
\text { pomorskie }\end{array}$ & 115 & 10 & 8.9 & $\mathrm{Nd}$ & $\mathrm{Nd}$ & No & T. spiralis \\
\hline
\end{tabular}

Nd-No data.

In 18 farms, only one of the tested pigs was infected with this parasite, while in 12 farms more than two pigs were infected. Epidemiological investigations were carried out on these 12 farms. Conducted serological tests (ELISA) and confirmative digestion indicated the various amount of pigs infected with Trichinella spp in those 12 farms. The highest prevalence $(100 \%)$ was found in 2019 on a farm (\#27) where only two pigs were bred and both of them were infected. The detailed information about the number of pigs in a herd, the number of infected pigs, and the prevalence on each pig farm is shown in Table 1. Additionally, in 7 of 12 farms in which epidemiological investigation was conducted, the 
presence of rodents, especially rats, was noticed. On these farms, the owners collected between 3 and 56 rat carcasses. Trichinella spp. infected rats occurred in four farms with various prevalence. Rats from three farms were not infected with Trichinella spp. (Table 1). Based on geographical data, we created a map with the locations of each farm (Figure 1). The farms were located in nine provinces. The highest number of farms with infected pigs were located in Wielkopolskie (11 farms), Zachodnio-Pomorskie (six farms) and Pomorskie (five farms) voivodeship.

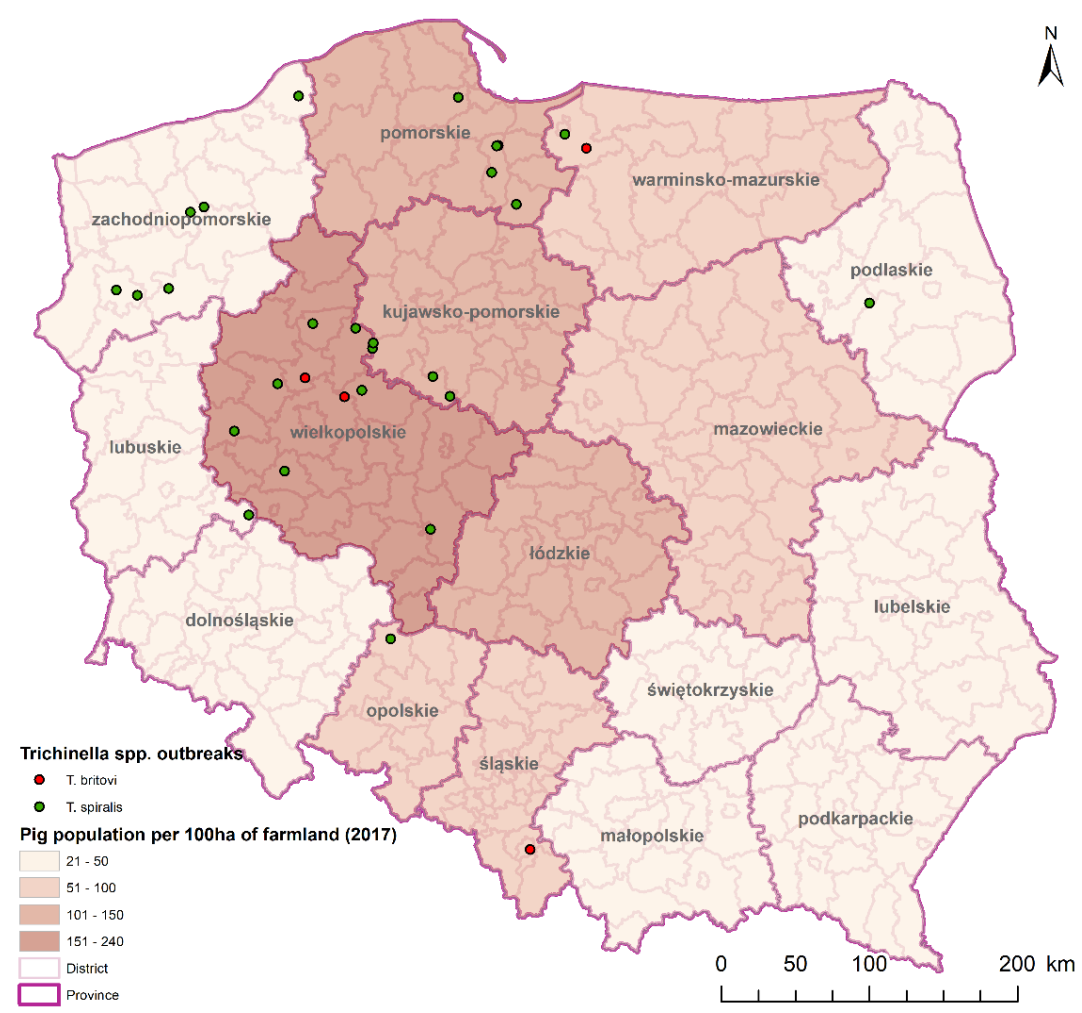

Figure 1. Geographical location of pig' farms on which Trichinella spp. infected pigs were discovered (range of data 2012-2020). On the map pig population per 100 ha of farmland was signed by intensity of red colour.

Species identification (using multiplex PCR) of collected isolates of larvae shows that in the majority of pigs infected with T. spiralis (26 farms), four pigs from four different farms were infected with T. britovi. Furthermore, we found:

- Moderate positive correlation between the number of tested pigs and the number of farms in which Trichinella spp. were detected $(\mathrm{r}=0.45, p<0.005)$;

- Strong positive correlation between the number of pigs in general in each province and the number of farms with infected pigs $(r=0.78, p<0.005)$;

- Strong positive correlation between the number of pigs per 100 ha of agricultural land in each province and the number of farms with infected pigs $(r=0.86, p<0.005)$ [16].

\section{Discussion}

In this study, we aimed to present the actual data of the occurrence of Trichinella spp. in pigs in Poland. The range of our study included a routine investigation for trichinellosis in pigs in the years 2012-2020. The discovered prevalence of infection in the tested pigs' population was $0.000088 \%$. The resulting prevalence is much lower compared to historical data, when in the years 1947-1956, 0.55\% of pigs infected with Trichinella spp. were found, and in the following years, $1957-1963$, a prevalence of $0.146 \%$ was recorded $[17,18]$. The other study, conducted between 1996 and 2004, showed an infection rate of $0.0054 \%$ [19]. Thus, when analyzing the obtained results over the decades, one can observe a downward 
trend of Trichinella spp. prevalence in pigs in Poland. The reason for the decrease in the percentage of pigs infected with Trichinella spp. is mainly the changes that have occurred in pig breeding, among others: intensification of breeding and introduction of biosecurity rules, improvement of welfare on farms, as well as introduction of industrial feed and prohibition of feeding pigs with meat and slaughter waste [20]. Despite this, Poland is one of the few European Union countries where Trichinella spp. in pigs is still regularly detected. In many European countries, including Austria, Belgium, Cyprus, Denmark, Ireland, Luxembourg, Malta, the Netherlands, Portugal, Slovenia, Sweden and England, no cases of pigs infected with this nematode have been reported for several years [21]. This is mainly the result of almost exclusively large-scale production and keeping animals in herds under controlled conditions. In Germany, detected cases of pig infections have been reported in recent years [22]. In the Czech Republic and Slovakia and other European Union countries, where pig production is low, pig trichinosis infections are also detected sporadically. Only in south-eastern Europe, where small farms dominate, e.g., in Bulgaria, Romania or Serbia, there are still relatively numerous infections of pigs with Trichinella spp. every year [23-25].

In the present study, almost all farms where an epidemiological investigation was conducted were small with a number of pigs less than 100. Polish pig production characterizes huge defragmentation and spread of small individual farms. The share of farms with herds of up to 200 heads in 2013 amounted to $97 \%$, and those with herds of 200 heads or more only constituted 3\% [26]. Changes in market conditions in recent decades, as well as growing requirements such as sanitary and veterinary standards, have resulted in intensive structural and modernization changes in slaughtering and pork processing. Between 2000 and 2015, the number of large companies in the meat sector increased by 25\% [27]. Currently, there are about $70 \%$ of individual, non-commercial and backyard farms, while the rest are operated by companies breeding $>200$ pigs in a herd [26]. The structure of pig production continues to change since the African Swine Fever epidemic occurred in recent years. This epidemic caused large losses in pig production, which resulted in the liquidation of several hundred thousand small pig farms [28]. Therefore, a continuous reduction in the number of small farms for these large-scale items is expected. This trend, however, does not exclude the possibility of Trichinella spp. infection in such farms. There are several conditions that must be fulfilled to completely protect pigs on a farm from parasite infections $[12,29]$. The very important characteristics on a farm that may have an impact on the occurrence of Trichinella spp. infection in pigs are: presence/absence of outdoor access, type of feed and presence of rodents which may be a vector for Trichinella spp. In our study, the majority of farms investigated presented indoor breeding systems, but some of them have also outdoor access, at least seasonally. The epidemiological investigation showed that the welfare found on these farms leaves much to be desired. Rats were found in seven farms, and in four farms, rats were also infected with Trichinella spp. This result indicates possible source of infection for pigs (ingestion of rats by pigs) on the investigated farms. The presence of rats in pig farms is not one-sided, however, because rats can both transfer the parasites to the farm and then spread them to the natural environment [30]. The single incidence of pig infection on a farm (e.g., farm \#4-\#11) can be explained by the first scenario where a rat can be caught and eaten by pigs and then introducing parasites into the farm.

In our study, also the second scenario is possible; we suspect it especially in farms $\# 2$ and \#12, where multiple infected rats were found. The epidemiological inquiry indicates that rats on these two farms were probably infected at the same time as pigs with feed contaminated by a bigger amount of fragmented, minced meat containing a relatively small number of Trichinella spp. larvae [31]. This conclusion we made based on epidemiological inquiry when evidence of illegal action taken by the owners, who probably used meat from hunted wild boars for pig feeding, was observed. In such a scenario, it is extremely important to conduct a thorough epidemiological investigation to stop the spreading of the parasite to the environment. Such a source of Trichinella spp. infection was traced during an epidemiological investigation of an outbreak in the Slovak Republic, which occurred 
after consumption of pork and/or smoked pork products. In this case, it was ascertained that the pig's owner was also a hunter and occasionally fed pigs with wild boar scraps [32].

An interesting case was farm \#27, in which only two pigs were bred. Animals were kept indoor in the majority, but seasonally they had access to the outdoors. On this farm, both pigs were infected with Trichinella spp. and each of the three trapped rats was infected too. It is extremely difficult to determine the source of infection on this farm; however, it seems probable that pigs acquired the infection outdoors. Similar findings were obtained during the epidemiological study of the outbreak which occurred in Bulgaria where T. spiralis larvae were detected in a brown rat (Rattus norvegicus) trapped near the small farm where the pigs were raised in the backyard. Consumption of those pigs' meat resulted in trichinellosis in eight people inhabiting the farm. Therefore, also in this outbreak, it is highly possible that the rats could be the source of Trichinella spp. infection in pigs [33]. A recent study of pigs reared under controlled conditions in Italy, with sows having outdoor access, indicates that animals being outside has a high probability of exposure to Trichinella spp. [20]. This observation is not new, but it does show how important it is to monitor pigs for Trichinella spp. presence, even in indoor farming conditions. This fact is even more important in case of the increasing number of organic farms, where pigs have access to the external environment, especially knowing that the undercooked pork meat from free-range pig farms has already been a source of Trichinella spp. infection. In such a situation, the importance of the presence of Trichinella spp. in wild animals increases [34]. The provinces (Wielkopolskie, Zachodniopomorskie and Pomorskie) where we found the highest number of pig farms with infected animals are characterized by a high number of wild boars infected with Trichinella spp. [35]. These regions are also characterized by the high number of pig farms, the high density of pigs on $100 \mathrm{~h}$ of agricultural lands, and the high number of pigs in general $[16,36]$. These variables indicate a statistically significant positive correlation with the number of farms in which infected pigs were discovered. It indicates the higher risk of Trichinella spp. infection in areas with a higher density of pig production. This, together with the high number of infected animals in the sylvatic cycle, increases that risk. Moreover, in our study, we discovered T. britovi in pigs on four farms. This highlights the possibility of getting the infection from the natural environment, as this species of Trichinella occurs in Poland mostly in wild carnivores [15].

During epidemiological investigations on each farm, we concluded that finding the source of infection in pig outbreaks is much more complicated, and is based on suspicions more than on true evidence. The presence of rats infected or illegal feeding of pigs with leftovers from hunting is suspected to be the cause of these infections. However, there is a huge difficulty in indicating when a proper source occurs, especially when the suspected source and pigs are infected with the same Trichinella species, which is what occurred in most of the present study. Thus, the species identification method alone is not enough. Better tools would help control the spread on farms [35,37], as would other types of parasites [38]. Such methods will be a chance to find a source and stop further spreading of the parasite. Accurate and timely tracing of sources would aid efforts to understand and control the sources of human exposure.

\section{Materials and Methods}

The prevalence of Trichinella spp. in pigs was assessed based on the results of official post-mortem examinations of carcasses according to EU Regulation 2015/1375, Annex I, Chapter III. Routine diagnosis was provided by accredited field laboratories of the VIS, which used the validated reference magnetic stirrer method for pooled sample digestion to detect Trichinella spp. (1375/2015). Muscle samples (diaphragm and/or intercostal muscles) from pigs that tested positive for Trichinella spp. were provided to the National Veterinary Research Institute, which is a National Reference Laboratory for trichinellosis in Poland (NVRI) to confirm the presence of larvae and to identify their species.

The origin of each infected pig was acquired by VIS. In the case where on a farm more than one pig was infected with Trichinella spp., epidemiological investigation on 
the given farm was conducted. The epidemiological investigation consisted of several actions taken together by the NVRI and regional VIS. First, we acquired information about the herd: size, feeding system, access to the natural environment, presence of rodents. Then, we collected rat carcasses obtained by owners from farms on which rodents were present. Muscles of rats were tested in NVRI for Trichinella spp. presence using the same digestion method according to EU Reg. 2015/1375. Then, we collected sera from each pig on a farm and we tested them using commercial ELISA tests [39]. In case of a positive serological result, the pigs from which the blood samples were obtained were slaughtered. Then, the diaphragm muscles from their carcasses were collected and tested with the digestion method to confirm Trichinella spp. infection and collect larvae for species identification. Species identification was provided in NVRI using multiplex PCR according to Zarlenga et al. [40] for five randomly collected individual larvae per isolate.

\section{Statistical Analysis}

The correlation between the number of tested pigs in each province and number of farms with infected pigs, number of pigs in general in each province and the number of farms with infected pigs, number of pigs per 100 ha of agricultural land in each province and number of farms with infected pigs were assessed by calculation of Pearson coefficient.

\section{Conclusions}

The increasingly rare finding of Trichinella spp. in pigs indicates the good effects of the changes that have occurred in the structure of pig production and the introduction of official regulations regarding the obligation to test the meat of pigs for Trichinella spp. The measurable effects of these activities include reports of the absence of cases of trichinellosis in humans caused by the consumption of infected pig meat. However, the data presented in this paper on the occurrence of pig infections in recent years indicate the need to continue the monitoring and routine tests for the presence of Trichinella spp. in this species of animals. Observations made during epidemiological investigations indicate the need to improve breeding conditions and broadly understand animal welfare in small individual farms, which are still the majority in Poland. This fact will become more important in the case of the increasing number of organic farms with the access of animals to the natural environment.

Epidemiological investigations have provided important information concerning possible transmission routes of Trichinella spp. However, the available tools were not always sufficient to properly determine the source of the parasites in a given outbreak. Therefore, there is a need to develop methods that can become a useful tool in the practical tracking of Trichinella spp. transmission.

Author Contributions: Conceptualization, E.B.-Z. and M.R.; methodology, E.B.-Z. and A.G.; writingE.B.-Z., W.K.-D., A.B. and M.W.-R.; writing-review and editing, M.R. and W.K.-D.; visualization, A.Z.-B.; supervision, T.C. All authors have read and agreed to the published version of the manuscript.

Funding: This research received no external funding.

Institutional Review Board Statement: Not applicable.

Informed Consent Statement: Not applicable.

Data Availability Statement: Not applicable.

Conflicts of Interest: The authors declare no conflict of interest.

\section{References}

1. Visciano, P.; Schirone, M. Rapid Methods for Assessing Food Safety and Quality. Foods 2020, 9, 533. [CrossRef]

2. Sas, A. Pig Meat per Capita Consumption in Poland. Available online: https://www.statista.com/statistics/440754/pig-meatper-capita-consumption-in-poland/ (accessed on 15 October 2021).

3. Fosse, J.; Seegers, H.; Magras, C. Foodborne zoonoses due to meat: A quantitative approach for a comparative risk assessment applied to pig slaughtering in Europe. Vet. Res. 2008, 39, 1-16. [CrossRef] 
4. Rawla, P.; Sharma, S. Trichinella Spiralis. StatPearls [Internet]. 2021. Available online: https://www.ncbi.nlm.nih.gov/books / NBK538511/ (accessed on 15 October 2021).

5. Golab, E.; Sadkowska-Todys, M. Epidemiology of human trichinellosis in Poland- currently and in the past. Wiad Parazytol. 2006, 52, 181-187.

6. Pozio, E. The broad spectrum of Trichinella hosts: From cold- to warm-blooded animals. Vet. Parasitol. 2005, 132, 3-11. [CrossRef]

7. Pozio, E. Trichinellosis in the European Union: Epidemiology, ecology and economic impact. Parasitol. Today 1998, 14, 35-38. [CrossRef]

8. Pozio, E. Searching for Trichinella: Not all pigs are created equal. Trends Parasitol. 2014, 30, 4-11. [CrossRef] [PubMed]

9. van Knapen, F. European proposal for alternative Trichinella control in domestic pigs. Fleischwirtschaft 1998, 78, 338-339.

10. Commission Implementing Regulation. EC No 2075/2005 of 5 December 2005 Laying Down Specific Rules on Official Controls for Trichinella in Meat. 2005. Available online: https:/ / eur-lex.europa.eu/legal-content/EN/ALL/?uri=CELEX\%3A32005R2075 (accessed on 6 October 2021).

11. Commission Implementing Regulation. EC No 2015/1375, Commission Implementing Regulation (EU) 2015/1375 of 10 August 2015 Laying Down Specific Rules on Official Controls for Trichinella in Meat. 2015. Available online: https:/ / eur-lex.europa.eu/legalcontent/EN/TXT/?uri=CELEX\%3A32015R1375 (accessed on 6 October 2021).

12. Commission Implementing Regulation (EU) 2020/1478 of 14 October 2020 Amending Implementing Regulation (EU) 2015/1375 as Regards Sampling, the Reference Method for Detection and Import Conditions Related to Trichinella control. 2020. Available online: https: / / eur-lex.europa.eu/eli/reg_impl/2020/1478/oj (accessed on 6 October 2021).

13. European Food Safety Authority; European Centre for Disease Prevention and Control. The European Union One Health Zoonoses Report 2019. EFSA J. 2021, 19, e06406. [CrossRef]

14. Moskwa, B.; Cybulska, A.; Kornacka, A.; Cabaj, W.; Bien, J. Wild boars meat as a potential source of human trichinellosis in Poland: Current data. Acta Parasitol. 2015, 60, 530-535. [CrossRef]

15. Bilska-Zajac, E.; Rozycki, M.; Gradziel-Krukowska, K.; Belcik, A.; Mizak, I.; Karamon, J.; Sroka, J.; Zdybel, J.; Cencek, T. Diversity of Trichinella species in relation to the host species and geographical location. Vet. Parasitol. 2020, 279, 109052. [CrossRef] [PubMed]

16. Statistics Poland. Farm Animals in 2017. Warsaw. 2018. Available online: https://stat.gov.pl/files/gfx/portalinformacyjny/pl/ defaultaktualnosci/5508/6/18/1/zwierzeta_gospodarskie_w_2017_roku.pdf (accessed on 15 October 2021).

17. Kozar, Z.; Ogielski, L. Trichinellosis of pigs in Poland in the post-war period with special reference to 1960-1962. Wiad Parazytol. 1965, 11, 245-283. [PubMed]

18. Kozar, Z.; Ramisz, A.; Kozar, M. Incidence of Trichinella spiralis in some domestic and wild living animals in Poland. Wiad Parazytol. 1965, 11, 285-298. [PubMed]

19. Cabaj, W. Wild and domestic animals as permanent Trichinella reservoir in Poland. Wiad Parazytol. 2006, 52, 175-179.

20. Pozio, E.; Celli, M.; Ludovisi, A.; Interisano, M.; Amati, M.; Gomez-Morales, M.A. Animal welfare and zoonosis risk: AntiTrichinella antibodies in breeding pigs farmed under controlled housing conditions. Parasit Vect. 2021, 14, 417. [CrossRef] [PubMed]

21. European Food Safety Authority. Available online: https:/ / www.efsa.europa.eu (accessed on 15 October 2021).

22. Pannwitz, G.; Mayer-Scholl, A.; Balicka-Ramisz, A.; Nockler, K. Increased Prevalence of Trichinella spp., Northeastern Germany, 2008. Emerg. Infect. Dis. 2010, 16, 936-942. [CrossRef]

23. Dobrescu, C.; Hriscu, H.; Emandi, M.; Zamfir, C.; Nemet, C. Consumption of untested pork contributed to over two-thousand clinical cases of human trichinellosis in Romania. Folia Parasitol. (Praha) 2014, 61, 558-560. [CrossRef] [PubMed]

24. Kurdova, R.; Muller, N.; Tsvetkova, N.; Michov, L.; Georgieva, D.; Ivanova, M.; Gottstein, B. Characterisation of Trichinella isolates from Bulgaria by molecular typing and cross-breeding. Vet. Parasitol. 2004, 123, 179-188. [CrossRef]

25. Zivojinovic, M.; Sofronic-Milosavljevic, L.; Cvetkovic, J.; Pozio, E.; Interisano, M.; Plavsic, B.; Radojicic, S.; Kulisic, Z. Trichinella infections in different host species of an endemic district of Serbia. Vet. Parasitol. 2013, 194, 136-138. [CrossRef] [PubMed]

26. Ziętara, W. Production of live pigs in Poland-Conditions and prospects. Ann. Parasitol. 2019, XXI, 101-110. [CrossRef]

27. Hryszko, K.; Szajner, P. Pork Market in Poland after the EU Accession. In Proceedings of the International Academic Conferences 7010084, International Institute of Social and Economic Sciences, Budapest, Hungary, 5-8 June 2018.

28. Woźniakowski, G.; Pejsak, Z.; Jabłoński, A. Emergence of African Swine Fever in Poland (2014-2021). Successes and Failures in Disease Eradication. Agriculture 2021, 11, 738. [CrossRef]

29. Regulation of the Minister of Agriculture and Rural Developement of March 3rd 2020 on the Detailed Conditions and Procedure for Granting Financial Aid in the Frame of an Action Animal Welfare" Covered by the Rural Areas Developement Program for 2014-2020. (Dz.U. z dnia 09.03.2020 r., poz. 38). Available online: http://isap.sejm.gov.pl/isap.nsf/DocDetails.xsp?id=WDU202 00000382 (accessed on 15 October 2021).

30. Murrell, K.D.; Stringfellow, F.; Dame, J.B.; Leiby, D.A.; Duffy, C.; Schad, G.A. Trichinella spiralis in an Agricultural Ecosystem. II. Evidence for Natural Transmission of Trichinella spiralis spiralis from Domestic Swine to Wildlife. J. Parasitol. 1987, 73, $103-109$. [CrossRef] [PubMed]

31. Bilska-Zajac, E.; Rozycki, M.; Antolak, E.; Belcik, A.; Gradziel-Krukowska, K.; Karamon, J.; Sroka, J.; Zdybel, J.; Cencek, T. Occurrence of Trichinella spp. in rats on pig farms. Ann. Agric. Environ. Med. 2018, 25, 698-700. [CrossRef] [PubMed] 
32. Reiterova, K.; Kincekova, J.; Snabel, V.; Marucci, G.; Pozio, E.; Dubinsky, P. Trichinella spiralis—Outbreak in the Slovak Republic. Infection 2007, 35, 87-93. [CrossRef] [PubMed]

33. Vutova, K.; Velev, V.; Chipeva, R.; Yancheva, N.; Svetlozara, P.; Tomov, T.; Pozio, E.; Robertson, L.J. Clinical and epidemiological descriptions from trichinellosis outbreaks in Bulgaria. Exp. Parasitol. 2020, 212, 107874. [CrossRef]

34. Papatsiros, V.G.; Boutsini, S.; Ntousi, D.; Stougiou, D.; Mintza, D.; Bisias, A. Detection and zoonotic potential of Trichinella spp. from free-range pig farming in Greece. Foodborne Pathog. Dis. 2012, 9, 536-540. [CrossRef]

35. Thompson, R.C.A. Parasite zoonoses and wildlife: One Health, spillover and human activity. Int. J. Parasitol. 2013, 43, 1079-1088. [CrossRef]

36. General Veterinary Inspectorate. Veterinary Statistical Reporting. Available online: https://www.wetgiw.gov.pl/publikacje/rrwsprawozdawczosc-statystyczna (accessed on 15 October 2021).

37. Mohandas, N.; Pozio, E.; La Rosa, G.; Korhonen, P.K.; Young, N.D.; Koehler, A.V.; Hall, R.S.; Sternberg, P.W.; Boag, P.R.; Jex, A.R.; et al. Mitochondrial genomes of Trichinella species and genotypes-A basis for diagnosis, and systematic and epidemiological explorations. Int. J. Parasitol. 2014, 44, 1073-1080. [CrossRef]

38. Tessema, S.K.; Raman, J.; Duffy, C.W.; Ishengoma, D.S.; Amambua-Ngwa, A.; Greenhouse, B. Applying next-generation sequencing to track falciparum malaria in sub-Saharan Africa. Malar J. 2019, 18, 268. [CrossRef]

39. Bruschi, F.; Gomez-Morales, M.A.; Hill, D.E. International Commission on Trichinellosis: Recommendations on the use of serological tests for the detection of Trichinella infection in animals and humans. Food Waterborne Parasitol. 2019,14 , e00032. [CrossRef]

40. Zarlenga, D.S.; Chute, M.B.; Martin, A.; Kapel, C.M. A multiplex PCR for unequivocal differentiation of all encapsulated and non-encapsulated genotypes of Trichinella. Int. J. Parasitol. 1999, 29, 1859-1867. [CrossRef] 